\title{
Investigation of the long-term stability of various tinctures belonging to the lamiaceae family by HPLC and spectrophotometry method
}

\author{
Beatrix Sik $^{1}$ (D) $\cdot$ Erika Hanczné Lakatos ${ }^{1}$ (D) $\cdot$ Viktória Kapcsándi $^{1}$ (D) $\cdot$ Rita Székelyhidi $^{1} \cdot$ Zsolt $^{\text {Ajtony }}{ }^{1}$ (D)
}

Received: 29 April 2021 / Accepted: 23 June 2021 / Published online: 2 July 2021

(c) The Author(s) 2021

\begin{abstract}
The aim of the current study was to analyze the stability of rosmarinic acid in ethanolic tinctures of lemon balm (Melissa officinalis L.), oregano (Origanum vulgare L.), peppermint (Mentha x piperita), rosemary (Rosmarinus officinalis L.), sage (Salvia officinalis L.), and thyme (Thymus vulgaris L.). High-performance liquid chromatography with diode-array detection (HPLC-DAD) was employed to monitor the concentration of the marker compound over a six month period. Furthermore, the tinctures were also evaluated for caffeic acid, total phenolic content, and 2,2-diphenyl-1-picrylhydrazyl (DPPH) scavenging activity. We observed that the concentration of rosmarinic acid in tincture stored in closed amber glasses at ambient temperature decreased significantly during 6-month storage. Furthermore, our study squarely confirms the fact that a part of rosmarinic acid is converted to caffeic acid. The tested tinctures can be listed in the following order according to the greatest stability of the marker compound: rosemary $>$ peppermint $>$ oregano $>$ lemon balm $>$ thyme $>$ sage. The results of the study indicated a linear relationship between DPPH values and total phenolic $\left(R^{2}=0.92\right)$ or rosmarinic acid $\left(R^{2}=0.85\right)$ contents.
\end{abstract}

Keywords Tincture $\cdot$ Stability $\cdot$ Lamiaceae $\cdot$ HPLC $\cdot$ Antioxidant activity $\cdot$ Total phenolic content

\section{Introduction}

The use of herbal preparations for various purposes has been practiced for centuries. Nowadays, these products are available in many forms, such as tablets, capsules, syrups, tinctures, decoctions, infusions, or injections. According to some predictions, the global revenue from these products is expected to reach USD\$ 140 billion by 2024 (Kumadoh et al. 2015; Lo and Shaw 2019). In our days, according to the World Health Organization (WHO 2019), about $88 \%$ of the world's population uses herbal products. For this reason, the stability of plant extracts throughout shelf life is essential to ensure the quality, effectiveness, and safety of commercial products (Gafner and Bergeron 2005). However, studies in this direction are considerably complex because herbal preparations contain numerous active ingredients, and in many cases, the concentration of these compounds is low. Moreover, the shelf life and biological activity of each component

Beatrix Sik

sik.beatrix@sze.hu

1 Department of Food Science, Széchenyi István University, Mosonmagyaróvár, Hungary are also variable, which makes determination more difficult (Thakur et al. 2011; Testoni et al. 2019).

Tinctures are typically alcohol and water extracts of plant materials. The alcohol content of the tinctures needs to be at least $20 \%(\mathrm{v} / \mathrm{v})$ to provide adequate shelf life, which is usually a minimum of one year for commercially available products. In spite of this, some research shows that the active ingredients in the tinctures degrade significantly after 3-6 months of storage at room temperature (Bilia et al. 2002; Prosen and Pendry 2016). It follows from these results that further studies are needed to determine the optimal storage conditions and shelf lives of the various plant extracts, thus helping to maximize the efficacy of these products and guaranteeing adequate quality for consumers (Romm et al. 2010; Kumadoh and Ofori-Kwakye 2017).

The stability study of tinctures and other herbal products is tested primarily by chromatographic determination of the marker components. For the study of stability, a combination of chromatographic methods (HPLC, GC) with mass spectrometry (MS) or the HPLC method with the UV-VIS technique is acceptable according to the monograph EMA/ HMPC/16641/2005 Rev3 (Anonymous 2018), which also determines that the permissible active substance degradation can be only $5-10 \%$ of the initial value. 
From a pharmaceutical point of view, many active ingredients obtained from plants have been known to possess a beneficial effect on human health. Nowadays, the interest in herbal extracts with high rosmarinic acid content has considerably increased due to their favorable pharmacological and biological properties. Rosmarinic acid is a secondary metabolite belonging to phenolic acids, and it is often used as a marker compound in the Nepetoideae subfamily of the Lamiaceae family (Mishra et al. 2020). From a chemical point of view, rosmarinic acid is a phenylpropanoid as the caffeic acid ester of 3,4-dihydroxyphenillactic acid (Shetty 2008). Primarily, the compound has an antioxidant effect (Bernatoniene et al. 2016); and the results of recent research have shown that rosmarinic acid has a preventive or therapeutic effect on neurodegenerative disorders (Fachel et al. 2019), diabetes mellitus (Runtuwene et al. 2016) or cancer (Swamy et al. 2018).

Although several studies have been conducted in the field of pharmacology to evaluate plant species of the Lamiaceae family, as far as we know, very little information is available on the long-term stability of the marker compound of the family in plant extracts. For this reason, our study aimed to determine the stability of rosmarinic acid, in various tinctures by HPLC-DAD technique. At the same time, we monitored the total phenolic content and measured the antioxidant activity of tinctures.

\section{Materials and methods}

\section{Standard and reagents}

The HPLC analytical standards of caffeic $(\geq 98 \%)$ and rosmarinic acid ( $\geq 98 \%)$ were purchased from Sigma-Aldrich (Hungary). The high purity deionized water with a resistivity of $18 \mathrm{M} \Omega \mathrm{cm}$ was generated with a Zeneer Power I system (Human Corporation, Korea). Furthermore, for the experiments, we used HPLC grade methanol (LGC Standards, Germany), analytical grade trifluoroacetic acid (Riedelde Haën, Germany), absolute ethanol (Merck, Germany), L-ascorbic acid (Sigma-Aldrich, Hungary), 2,2-diphenyl1-picrylhydrazyl (Sigma-Aldrich, Hungary), gallic acid (Merck, Germany), Folin-Ciocalteu reagent (Merck, Germany), and anhydrous sodium carbonate (Riedel-de Haën, Germany).

\section{Plant material}

The leaves of six Lamiaceae plants, namely, lemon balm (Melissa officinalis L.), oregano (Origanum vulgare L.), peppermint (Mentha x piperita), rosemary (Rosmarinus officinalis L.), sage (Salvia officinalis L.), and thyme (Thymus vulgaris L.) were collected from Hungary in the summer of
2018. The air-dried samples were ground to a fine powder and stored away from light at $5{ }^{\circ} \mathrm{C}$ until analysis.

\section{Tincture preparation}

The hydroethanolic extracts (tinctures) were prepared from

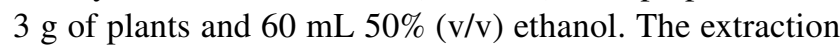
was performed by maceration with a laboratory shaker (Elpan, Poland) in a closed Erlenmeyer flask at room temperature for $2 \mathrm{~h}$. The extracts were filtered through Whatman No 1 filter paper, and the filtrates were used as tinctures. Standard rosmarinic acid as control was dissolved in 50\% $(\mathrm{v} / \mathrm{v})$ ethanol similar to tinctures, to obtain a concentration of $500 \mu \mathrm{g} \mathrm{mL}^{-1}$.

\section{Stability testing}

Each tincture and the rosmarinic acid standard solution was transferred $(4 \mathrm{~mL})$ into six amber glass bottles and stored in a closed box at ambient temperature for six months simulating standard "home" storage conditions. The air humidity was $45 \pm 5 \%$ during the storage period. The tinctures and rosmarinic acid standard solution were analyzed at the initial time and then monthly, which corresponds to the 27th, 55th, 86th, 113th, 141th, and 168th days. The limit of acceptance of rosmarinic acid as a marker compound of Lamiaceae plants was considered $90 \%$ from the initial assay value of the tinctures.

\section{HPLC analysis for rosmarinic acid and caffeic acid}

Chromatographic analyses were carried out on a LaCrome 7000 (Merck Hitachi, Germany) system equipped with an L-7000 pump, L-7250 autosampler, L-7350 column thermostat, and L-7450 diode-array detector. The phenolic compounds of tinctures were determined by HPLC-DAD as previously described (Sik et al. 2020). Separation and quantification were carried out using a Purospher Star C18 $(250 \times 4.6 \mathrm{~mm}$ i.d., particle size $5 \mu \mathrm{m})$ analytical column at a flow rate $1 \mathrm{~mL} \mathrm{~min}{ }^{-1}$ and a temperature of $35^{\circ} \mathrm{C}$. The quantification was done at a wavelength of $330 \mathrm{~nm}$. Each sample was filtered through a $0.22 \mu \mathrm{m}$ PVDF membrane before being directly injected $(2 \mu \mathrm{L})$ into the HPLC column. Data processing was performed by using D-7000 HPLC System Manager 4.0 (HSM) software.

\section{HPLC method validation}

The applied analytical method was validated for the measurement of phenolic compounds in tinctures of six Lamiaceae plants. The following performance characteristics were evaluated: linearity, precision (repeatability), accuracy, limit of quantification (LOQ), and limit of detection (LOD). 
The linearity was analyzed using a calibration curves. Stock solutions of caffeic acid $\left(1 \mathrm{mg} \mathrm{mL}^{-1}\right)$ and rosmarinic acid ( $5 \mathrm{mg} \mathrm{mL}^{-1}$ ) were prepared in methanol. Standard solutions were subsequently prepared by dilution with $50 \%(\mathrm{v} / \mathrm{v})$ methanol in the concentration range of $2-100 \mu \mathrm{g} \mathrm{mL}^{-1}$ for caffeic acid and $10-4000 \mu \mathrm{g} \mathrm{mL} \mathrm{m}^{-1}$ for rosmarinic acid.

The accuracy was determined by analyzing the phenolic compound recovery percentage in tinctures. Known amounts of standard solutions containing caffeic acid $\left(15 \mu \mathrm{g} \mathrm{mL}^{-1}\right)$ and rosmarinic acid $\left(1500 \mu \mathrm{g} \mathrm{mL}^{-1}\right.$ and $\left.300 \mu \mathrm{g} \mathrm{mL}^{-1}\right)$ were added individually to prepared ethanolic extracts. Each solution was injected three times into the column, and the results were calculated as percent recovery (\%) by comparison of the phenolic compound amount in spiked and nonspiked plant tinctures.

The precision of the method was evaluated in terms of repeatability. Repeatability was assessed by three independent injections of tinctures and rosmarinic acid standard solution $\left(500 \mu \mathrm{g} \mathrm{mL}^{-1}\right)$ on the same day. Precision was expressed as a relative standard deviation (RSD\%) of the retention times and amounts of extracted phenolic compounds.

The LOQ and LOD under the present chromatographic conditions were determined at a signal-to-noise ratio of 10 and 3 .

\section{Spectrophotometric methods}

Measurements of the total phenolics assay and DPPH free radical scavenging activity of the tinctures were performed with a Spectroquant Pharo 100 (Merck, Germany) spectrophotometer.

\section{Total phenolics assay}

For the determination of total phenolic content, a modification of the method proposed by Singleton and Rossi (1965) was used. Briefly, a fivefold diluted tincture $(50 \mu \mathrm{L})$ was mixed with $1.5 \mathrm{~mL}$ of water, $2.5 \mathrm{~mL}$ of Folin-Ciocalteu reagent $(10 \%, \mathrm{v} / \mathrm{v})$, and $2 \mathrm{~mL}$ of sodium carbonate solution

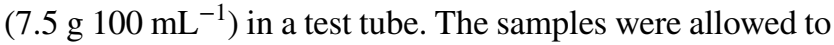
stand in the dark at room temperature for $90 \mathrm{~min}$. The absorbances were measured $(n=3)$ at $725 \mathrm{~nm}$ versus the blank. Gallic acid was used as a standard (100-1000 $\left.\mu \mathrm{g} \mathrm{mL}^{-1}\right)$ for the calibration curve $\left(0.0012 \mathrm{x}+0.0206, R^{2}=0.9996\right)$, and the results were expressed as mg of gallic acid equivalents per gram of dry plant material (mg GAE $\left.\mathrm{g}^{-1}\right)$.

\section{2,2-diphenyl-1-picrylhydrazyl scavenging assay}

In this method, the 2,2-diphenyl-1-picrylhydrazyl (DPPH) assay was conducted according to the following procedure. A solution of the radical is prepared by dissolving $3.9 \mathrm{mg}$ of DPPH in $100 \mathrm{~mL}$ of methanol. An aliquot of each diluted extract $(0.05 \mathrm{~mL})$ was added to a DPPH solution $(4.950 \mathrm{~mL})$ and the reaction mixture was kept in the dark for $1 \mathrm{~h}$ at room temperature and the absorbance was read at $517 \mathrm{~nm}$. The half-inhibitory concentration $\left(\mathrm{IC}_{50}\right)$, i.e., the concentration of sample providing $50 \%$ of radical scavenging activity was obtained through interpolation of linear regression analysis. The $1 / \mathrm{IC}_{50}$ coefficient was also calculated to determine the correlation between antioxidant activity and the rosmarinic acid and total phenolic content of the tested plant extracts. L-ascorbic acid was used as a standard (40-800 $\left.\mu \mathrm{g} \mathrm{mL}^{-1}\right)$ for calibration curve $\left(0.0012 \mathrm{x}+0.0334, R^{2}=0.9991\right)$. Rosmarinic acid and caffeic acid were used as the positive control, and the DPPH radical scavenging activity was expressed as $\mathrm{mg}$ of L-ascorbic acid equivalents per gram of dry plant material ( $\mathrm{mg} \mathrm{AAE}^{-1}$ ) by the following equation:

$\mathrm{DPPH}$ radical scavenging activity $=\frac{\mathrm{IC} 50_{\mathrm{L}-\text { ascorbicacid }}}{\mathrm{IC} 50_{\text {plantextract } / \text { standard }}} \times 10^{3}$

\section{Statistical analysis}

Data were expressed as the mean $(n=3) \pm$ standard deviation (SD). Analyses of variance (ANOVA) were used to compare the significant difference for the results $(95 \%$ confidence level, $p \leq 0.05)$. The statistical analyses were performed using LibreOffice Calc 6.0 software.

\section{Results}

\section{Identification and measurements of rosmarinic acid and caffeic acid by HPLC}

In this study, tinctures were analyzed directly without sample preparation, thus minimizing the possibility of degradation of active ingredients. Figure 1 shows the chromatograms measured for tinctures and rosmarinic acid standard solution before and after 168 days. As seen from the chromatograms, the phenolic compounds successfully separated from each other. Identification was applied by comparing the retention times and the UV spectra of standard solutions. The amounts of phenolic compounds were calculated using calibration curves and expressed as $\mu \mathrm{g} \mathrm{mL}^{-1}$. The most common phenolic acids were rosmarinic acid $\left(146.3 \pm 0.8 \mu \mathrm{g} \mathrm{mL}^{-1}-137\right.$ $\left.2 \pm 14 \mu \mathrm{g} \mathrm{mL}^{-1}\right)$ and caffeic acid $\left(11.80 \pm 0.33 \mu \mathrm{g} \mathrm{mL}^{-1}-3\right.$ $7.54 \pm 0.16 \mu \mathrm{g} \mathrm{mL}^{-1}$ ).

The chromatographic profiles of tinctures suggest that a part of rosmarinic acid decomposes into caffeic acid. As shown in Fig. 1, among specimens of the genus Lamiaceae, sage showed the most rosmarinic acid decomposition, while the increasing of caffeic acid was most significant in lemon balm. It is to be noted that at $330 \mathrm{~nm}$ some unidentified 

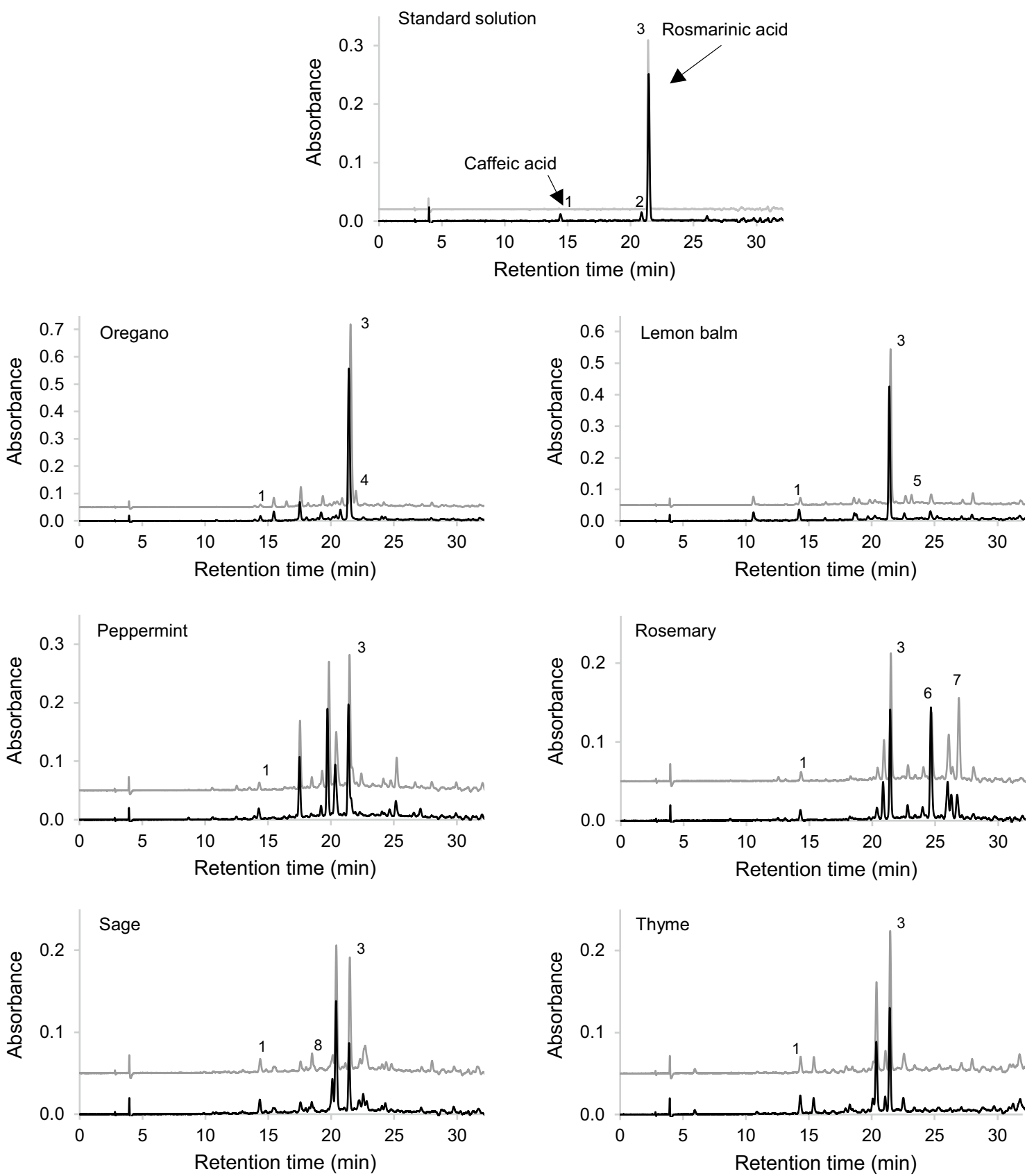

Fig. 1 Variation of typical HPLC chromatograms of tinctures and rosmarinic acid standard $(500 \mu \mathrm{g} / \mathrm{mL})$ under the tested conditions at a wavelength of $330 \mathrm{~nm}$ at the initial (grey) and final day (black)

peaks also decomposed. This is most noticeable in the case of oregano, lemon balm, and rosemary, marked with 4, 5, and 7 number of peaks. Furthermore, in some cases, e.g., for rosemary and sage, a significant increase in unidentified peaks was also observed, which marked with 6 and 8 , respectively. The chromatographic profile of the standard solution unequivocally confirms the degradation of rosmarinic acid to caffeic acid (marked with 1) and other compounds (marked with 2). The quantitative change in identified peaks will be discussed later in the manuscript. Overall, based on the HPLC analysis, rosmarinic acid was the major component in oregano, lemon balm, rosemary, and thyme tinctures, proving that it is excellent as a marker compound.

\section{HPLC method validation}

The performance characteristics of the applied analytical method were evaluated based on system linearity, 
repeatability, recovery, LOD, and LOQ. The results are summarized in Tables 1 and 2.

Different concentration values of two phenolic acid (caffeic acid and rosmarinic acid) compounds were investigated to determine the linearity range for the method developed. Determination coefficients $\left(R^{2}\right)$ of both calibration curves were above 0.9996 , which indicates the linearity of the HPLC method. The LOD determined in tinctures ranged between $0.6 \mu \mathrm{g} \mathrm{mL}^{-1}$ and $1.8 \mu \mathrm{g} \mathrm{mL}^{-1}$ for caffeic acid and rosmarinic acid, respectively, and the corresponding LOQ values were $2 \mu \mathrm{g} \mathrm{mL}^{-1}$ and $6 \mu \mathrm{gL}^{-1}$ (Table 1).

The repeatability of the method was evaluated by the relative standard deviation (RSD\%) of the retention times and amounts of the individual phenolic compounds within tinctures. On the whole the RSD values were below 3.0\%. A relationship between repeatability and the concentration of extracted compounds was also observed, i.e., higher amounts of phenolic compounds showed lower relative standard deviations. A recovery study has been conducted to confirm the accuracy of the method developed. The overall recovery percentages were in the range of $94.2 \pm 3.6-103.8 \pm 3.2 \%$ and $91.1 \pm 2.7-98.5 \pm 2.1 \%$ for caffeic acid and rosmarinic acid, respectively (Table 2).

The above results demonstrate that the HPLC method is adequate for the quantitative determination of phenolic compounds in Lamiaceae tinctures. In consequence, the validated method was used for the stability study of phenolic acids in oregano, lemon balm, peppermint, rosemary, sage, and thyme tincture samples.

\section{Stability of rosmarinic acid and caffeic acid}

The effect of 168-day storage on the rosmarinic acid and caffeic acid content of the plant tinctures is presented in Table 3. The degradations of the amounts of phenolic acid compounds in the very beginning were considered to be
Table 1 Calibration curves, limit of detection and limit of quantification data of investigated analyte by HPLCDAD

\begin{tabular}{lllllll}
\hline Phenolic compound & $\begin{array}{l}\text { Retention } \\
\text { time }(\mathrm{min})\end{array}$ & $\begin{array}{l}\text { Linearity range } \\
\left(\mu \mathrm{g} \mathrm{mL} \mathrm{m}^{-1}\right)\end{array}$ & Slope $\left(\mu \mathrm{gL}^{-1}\right)$ & $R^{2 \mathrm{a}}$ & $\begin{array}{l}\mathrm{LOD}^{\mathrm{b}}(\mu \mathrm{g} \\
\left.\mathrm{mL}^{-1}\right)\end{array}$ & $\begin{array}{l}\mathrm{LOQ}^{\mathrm{c}} \\
(\mu \mathrm{g} \\
\mathrm{mL}\end{array}$ \\
\hline Caffeic acid & 14.33 & $2-100$ & 4723 & 0.9998 & 0.6 & 2 \\
Rosmarinic acid & 21.42 & $10-4000$ & 2584 & 0.9996 & 1.8 & 6 \\
\hline
\end{tabular}

${ }^{\mathrm{a}} R^{2}$ : determination coefficient

${ }^{\mathrm{b}} \mathrm{LOD}$ :limit of detection

${ }^{\mathrm{c}} \mathrm{LOQ}$ : limit of quantification

Table 2 Repeatability and accuracy of caffeic acid and rosmarinic acid in six various tinctures and standard mix solution

\begin{tabular}{|c|c|c|c|c|c|c|c|}
\hline \multirow[t]{2}{*}{ Phenolic compound } & \multicolumn{3}{|c|}{ Repeatability (RSD\%) } & \multicolumn{4}{|l|}{ Accuracy } \\
\hline & $\begin{array}{l}\text { Retention time } \\
\text { (min) }\end{array}$ & $\begin{array}{l}\text { Peak area } \\
\text { (initial day) }\end{array}$ & $\begin{array}{l}\text { Peak area } \\
\text { (final day) }\end{array}$ & $\begin{array}{l}\text { Unspiked sample } \\
\left(\mu \mathrm{g} \mathrm{m}^{-1}\right)\end{array}$ & $\begin{array}{l}\text { Spiked sample } \\
\left(\mu \mathrm{g} \mathrm{mL}^{-1}\right)\end{array}$ & Recovery (\%) & $\operatorname{RSD}^{\mathrm{a}}(\%)$ \\
\hline \multicolumn{8}{|l|}{ Caffeic acid } \\
\hline Lemon balm & 0.25 & 0.6 & 0.8 & 22.31 & 37.87 & 103.8 & 3.2 \\
\hline Oregano & 0.42 & 1.8 & 2.9 & 11.68 & 26.16 & 96.5 & 4.8 \\
\hline Peppermint & 0.23 & 1.2 & 0.8 & 13.65 & 28.48 & 97.3 & 3.8 \\
\hline Rosemary & 0.20 & 2.8 & 3.0 & 11.58 & 26.20 & 97.4 & 2.9 \\
\hline Sage & 0.20 & 0.9 & 1.5 & 17.41 & 31.54 & 94.2 & 3.6 \\
\hline Thyme & 0.18 & 2.0 & 2.2 & 20.59 & 34.90 & 95.4 & 2.6 \\
\hline Standard & 0.10 & 1.2 & 2.5 & - & - & - & - \\
\hline \multicolumn{8}{|l|}{ Rosmarinic acid } \\
\hline Lemon balm & 0.19 & 0.5 & 0.4 & 863.2 & 2297 & 95.6 & 2.4 \\
\hline Oregano & 0.23 & 1.0 & 1.1 & 1375 & 2853 & 98.5 & 2.1 \\
\hline Peppermint & 0.22 & 0.7 & 1.1 & 345.2 & 638.2 & 97.7 & 3.4 \\
\hline Rosemary & 0.20 & 0.8 & 1.2 & 286.4 & 568.7 & 91.1 & 2.7 \\
\hline Sage & 0.26 & 0.4 & 0.6 & 244.9 & 533.5 & 96.2 & 1.9 \\
\hline Thyme & 0.33 & 0.7 & 0.4 & 303.4 & 590.0 & 95.5 & 4.2 \\
\hline Standard & 0.08 & 0.5 & 1.2 & - & - & - & - \\
\hline
\end{tabular}

${ }^{\mathrm{a}} \mathrm{RSD}(\%)$ : relative standard deviation 
Table 3 Stability profile of caffeic acid and rosmarinic acid of six Lamiaceae tinctures at ambient temperature over 168-day storage

\begin{tabular}{|c|c|c|c|c|c|c|c|}
\hline \multirow[t]{2}{*}{ Tinctures/standard } & \multirow{2}{*}{$\begin{array}{l}\text { Storage period } \\
\text { (days) }\end{array}$} & \multicolumn{3}{|l|}{ Caffeic acid } & \multicolumn{3}{|c|}{ Rosmarinic acid } \\
\hline & & $\mu \mathrm{g} \mathrm{mL}^{-1} \pm \mathrm{SD}$ & $\Delta \mathrm{c}^{\mathrm{a}}\left(\mu \mathrm{g} \mathrm{mL}^{-1}\right)$ & $\operatorname{Deg} \%^{\mathrm{b}}$ & $\mu \mathrm{g} \mathrm{mL}^{-1} \pm \mathrm{SD}$ & $\Delta \mathrm{c}^{\mathrm{a}}\left(\mu \mathrm{g} \mathrm{mL}^{-1}\right)$ & $\operatorname{Deg} \%^{\mathrm{b}}$ \\
\hline \multirow[t]{7}{*}{ Lemon balm } & 0 & $24.23 \pm 1.37^{\mathrm{a}}$ & - & - & $864.2 \pm 4.6^{\mathrm{a}}$ & - & - \\
\hline & 27 & $30.78 \pm 0.44^{\mathrm{b}}$ & 6.55 & -27.0 & $801.5 \pm 2.1^{\mathrm{b}}$ & -62.7 & 7.2 \\
\hline & 55 & $30.57 \pm 0.31^{\mathrm{c}}$ & 6.34 & -26.2 & $724.5 \pm 8.8^{\mathrm{c}}$ & -140 & 16.1 \\
\hline & 86 & $34.15 \pm 0.58^{\mathrm{d}}$ & 9.92 & -40.8 & $726.0 \pm 11.5^{\mathrm{c}}$ & -138 & 16.0 \\
\hline & 113 & $34.03 \pm 0.18^{\mathrm{d}}$ & 9.80 & -40.4 & $723.3 \pm 1.2^{\mathrm{c}}$ & -141 & 16.3 \\
\hline & 141 & $37.47 \pm 0.09^{\mathrm{e}}$ & 13.2 & -54.6 & $715.1 \pm 3.6^{\mathrm{d}}$ & -149 & 17.2 \\
\hline & 168 & $37.54 \pm 0.16^{\mathrm{e}}$ & 14.3 & -54.9 & $715.1 \pm 2.7^{\mathrm{d}}$ & -149 & 17.2 \\
\hline \multirow[t]{7}{*}{ Oregano } & 0 & $13.42 \pm 1.12^{\mathrm{a}}$ & - & - & $1372 \pm 14^{\mathrm{a}}$ & - & - \\
\hline & 27 & $17.36 \pm 0.64^{\mathrm{b}}$ & 3.94 & -29.4 & $1243 \pm 6^{b}$ & -129 & 9.4 \\
\hline & 55 & $17.95 \pm 0.53^{\mathrm{c}}$ & 4.53 & -33.8 & $1210 \pm 5^{\mathrm{c}}$ & -162 & 11.8 \\
\hline & 86 & $18.78 \pm 0.55^{\mathrm{c}}$ & 5.36 & -40.0 & $1200 \pm 15^{\mathrm{c}}$ & -172 & 12.6 \\
\hline & 113 & $19.07 \pm 0.22^{\mathrm{c}}$ & 5.65 & -42.1 & $1193 \pm 2^{c}$ & -179 & 13.0 \\
\hline & 141 & $19.17 \pm 0.30^{\mathrm{c}}$ & 5.75 & -42.8 & $1168 \pm 4^{\mathrm{d}}$ & -204 & 14.9 \\
\hline & 168 & $20.21 \pm 0.30^{\mathrm{d}}$ & 6.79 & -50.6 & $1146 \pm 13^{\mathrm{e}}$ & -226 & 16.5 \\
\hline \multirow[t]{7}{*}{ Peppermint } & 0 & $14.24 \pm 0.16^{\mathrm{a}}$ & - & - & $414.5 \pm 3.3^{\mathrm{a}}$ & - & - \\
\hline & 27 & $17.35 \pm 0.45^{\mathrm{b}}$ & 3.11 & -21.8 & $394.0 \pm 0.6^{\mathrm{b}}$ & -20.5 & 5.0 \\
\hline & 55 & $17.58 \pm 0.22^{\mathrm{b}}$ & 3.34 & -23.5 & $380.8 \pm 1.1^{\mathrm{c}}$ & -33.7 & 8.1 \\
\hline & 86 & $18.15 \pm 0.15^{\mathrm{c}}$ & 3.91 & -27.4 & $375.6 \pm 0.6^{\mathrm{d}}$ & -38.9 & 9.4 \\
\hline & 113 & $18.60 \pm 0.28^{c}$ & 4.36 & -30.5 & $370.8 \pm 1.5^{\mathrm{e}}$ & -43.7 & 10.5 \\
\hline & 141 & $19.39 \pm 0.15^{\mathrm{d}}$ & 5.15 & -36.1 & $365.2 \pm 5.1^{\mathrm{e}}$ & -49.3 & 11.9 \\
\hline & 168 & $19.65 \pm 0.30^{\mathrm{d}}$ & 5.41 & -37.9 & $348.9 \pm 4.1^{\mathrm{f}}$ & -65.6 & 15.8 \\
\hline \multirow[t]{7}{*}{ Rosemary } & 0 & $11.80 \pm 0.33^{\mathrm{a}}$ & - & - & $291.8 \pm 2.3^{\mathrm{a}}$ & - & - \\
\hline & 27 & $13.78 \pm 0.34^{\mathrm{b}}$ & 1.98 & -16.8 & $276.1 \pm 0.7^{\mathrm{b}}$ & -15.7 & 5.4 \\
\hline & 55 & $13.67 \pm 0.39^{\mathrm{b}}$ & 1.87 & -15.7 & $268.2 \pm 1.7^{\mathrm{c}}$ & -23.6 & 8.1 \\
\hline & 86 & $13.50 \pm 0.26^{\mathrm{b}}$ & 1.70 & -14.4 & $262.3 \pm 2.8^{\mathrm{d}}$ & -29.5 & 10.1 \\
\hline & 113 & $13.90 \pm 0.23^{\mathrm{b}}$ & 2.10 & -17.8 & $262.5 \pm 1.2^{\mathrm{d}}$ & -29.3 & 10.0 \\
\hline & 141 & $13.96 \pm 0.42^{\mathrm{b}}$ & 2.16 & -18.2 & $255.7 \pm 1.2^{\mathrm{e}}$ & -36.1 & 12.4 \\
\hline & 168 & $14.36 \pm 0.42^{\mathrm{b}}$ & 2.56 & -21.6 & $250.8 \pm 2.9^{\mathrm{e}}$ & -41.0 & 14.1 \\
\hline \multirow[t]{7}{*}{ Sage } & 0 & $18.51 \pm 0.63^{\mathrm{a}}$ & - & - & $249.7 \pm 0.9^{\mathrm{a}}$ & - & - \\
\hline & 27 & $19.46 \pm 0.40^{\mathrm{b}}$ & 0.95 & -5.4 & $232.8 \pm 0.7^{\mathrm{b}}$ & -16.9 & 6.8 \\
\hline & 55 & $19.81 \pm 0.36^{\mathrm{b}}$ & 1.30 & -7.0 & $177.0 \pm 1.9^{c}$ & -72.7 & 29.1 \\
\hline & 86 & $20.59 \pm 0.53^{\mathrm{b}}$ & 2.08 & -11.4 & $169.1 \pm 0.6^{\mathrm{d}}$ & -80.6 & 32.3 \\
\hline & 113 & $22.37 \pm 0.32^{\mathrm{c}}$ & 3.86 & -21.0 & $166.7 \pm 1.5^{\mathrm{d}}$ & -83.0 & 33.2 \\
\hline & 141 & $23.13 \pm 0.32^{\mathrm{d}}$ & 4.62 & -25.1 & $162.2 \pm 1.1^{\mathrm{e}}$ & -87.5 & 35.0 \\
\hline & 168 & $23.52 \pm 0.34^{\mathrm{d}}$ & 5.01 & -27.0 & $146.3 \pm 0.8^{\mathrm{f}}$ & -103 & 41.4 \\
\hline \multirow[t]{7}{*}{ Thyme } & 0 & $21.15 \pm 0.04^{\mathrm{a}}$ & - & - & $310.2 \pm 2.3^{\mathrm{a}}$ & - & - \\
\hline & 27 & $23.19 \pm 0.85^{\mathrm{b}}$ & 2.04 & -9.5 & $274.5 \pm 2.5^{\mathrm{b}}$ & -35.7 & 11.5 \\
\hline & 55 & $23.37 \pm 0.27^{b}$ & 2.22 & -10.4 & $237.3 \pm 2.1^{\mathrm{c}}$ & -72.9 & 23.5 \\
\hline & 86 & $23.50 \pm 0.19^{\mathrm{b}}$ & 2.35 & -11.1 & $237.6 \pm 2.0^{\mathrm{c}}$ & -72.6 & 23.4 \\
\hline & 113 & $23.49 \pm 0.43^{\mathrm{b}}$ & 2.34 & -11.1 & $237.0 \pm 0.7^{\mathrm{c}}$ & -73.2 & 23.6 \\
\hline & 141 & $24.03 \pm 0.54^{\mathrm{b}}$ & 2.88 & -13.5 & $235.1 \pm 3.0^{c}$ & -75.1 & 24.2 \\
\hline & 168 & $25.33 \pm 0.47^{\mathrm{c}}$ & 4.18 & -19.7 & $224.5 \pm 0.9^{\mathrm{d}}$ & -85.7 & 27.6 \\
\hline \multirow[t]{7}{*}{ Rosmarinic acid } & 0 & $<$ LOD & - & - & $480.7 \pm 2.2^{\mathrm{a}}$ & - & - \\
\hline & 27 & $2.63 \pm 0.15^{\mathrm{a}}$ & 2.63 & -2.63 & $465.2 \pm 2.8^{\mathrm{b}}$ & -15.5 & 3.1 \\
\hline & 55 & $2.98 \pm 0.16^{\mathrm{a}}$ & 2.98 & -2.98 & $455.1 \pm 2.2^{\mathrm{c}}$ & -25.6 & 5.3 \\
\hline & 86 & $4.88 \pm 0.22^{\mathrm{b}}$ & 4.88 & -4.88 & $446.5 \pm 3.1^{\mathrm{d}}$ & -34.2 & 7.1 \\
\hline & 113 & $6.72 \pm 0.52^{\mathrm{b}}$ & 6.72 & -6.72 & $441.3 \pm 2.1^{\mathrm{d}}$ & -39.4 & 8.1 \\
\hline & 141 & $8.84 \pm 0.43^{c}$ & 8.84 & -8.84 & $438.3 \pm 1.5^{\mathrm{e}}$ & -42.4 & 8.9 \\
\hline & 168 & $10.03 \pm 0.61^{\mathrm{c}}$ & 10.0 & -10.0 & $434.2 \pm 2.1^{\mathrm{e}}$ & -46.5 & 9.6 \\
\hline
\end{tabular}

Different letters (a, b, c, d, e, and f) denote significant differences $(p \leq 0.05)$

${ }^{\mathrm{a}} \Delta \mathrm{c}$ : change of concentration

${ }^{\mathrm{b}}$ Deg\%: percent degradation 
$0 \%$, excluding the differences in concentrations. The results indicated a highly significant difference $(p \leq 0.05)$ between the initial and finished phenolic acid concentrations for all species. As shown in Table 3, the caffeic acid content in all tinctures started to increase after 27-day storage, while the rosmarinic acid content decreased. Basically, between the first and the last day of storage, the decreases in rosmarinic acid were $14.1 \%, 15.8 \%, 16.5 \%, 27.6 \%$, and $41.4 \%$ for rosemary, peppermint, oregano, lemon balm, thyme, and sage, respectively. The highest quantitative change in caffeic acid concentration was observed for lemon balm (-54.9\%), followed by oregano $(-50.6 \%)$, peppermint $(-37.9)$, sage $(-27.0 \%)$, rosemary $(-21.6 \%)$, and thyme $(-19.7 \%)$. The steady concentration level of both phenolic acids had been reached only in lemon balm and rosemary after 141 days. The degradation tendency of standard rosmarinic acid was also monitored during the 168-day of storage. In this case, we observed much lower decomposition values. During the six-month storage period, the degradation of the rosmarinic acid did not exceed the limit of acceptance. Table 3 also shows the changes in rosmarinic and caffeic acid in $\mu \mathrm{g} \mathrm{mL}^{-1}$. However, these results show that no linear relationship was found between the degradation of rosmarinic acid and the increase in caffeic acid.

\section{Total phenolic and antioxidant characteristics}

The total phenolic content and antioxidant properties of prepared tinctures are presented in Table 4. As can be seen, the initial total phenolic contents of the various Lamiaceae tinctures as determined using the Folin-Ciocalteu colorimetric method were in the range of $34.1 \pm 1.1 \mathrm{mg}$ GAE g ${ }^{-1}-93.4 \pm 2.2 \mathrm{mg} \mathrm{GAE} \mathrm{g}^{-1}$. During the 168-day storage at room temperature, the total phenolic contents of tinctures were also monitored, but slight changes were observed in this respect, e.g., the total phenolic contents in sage tincture decreased from $34.1 \pm 1.1 \mathrm{mg} \mathrm{GAE} \mathrm{g}^{-1}$ to $31.4 \pm 0.9 \mathrm{mg} \mathrm{GAE} \mathrm{g}^{-1}$, which represented a reduction of $7.8 \%$ ( $p \leq 0.05$ ). For rosemary $11.6 \%$ (from $38.8 \pm 0.4 \mathrm{mg}$ $\mathrm{GAE} \mathrm{g}^{-1}$ to $43.3 \pm 1.3 \mathrm{mg} \mathrm{GAE} \mathrm{g}^{-1}$ ) increase in the total phenolic content is observed during the storage period. A similar tendency was indicated for peppermint $(7.9 \%$, from $65.8 \pm 1.2 \mathrm{mg} \mathrm{GAE} \mathrm{g}^{-1}$ to $70.9 \pm 0.5 \mathrm{mg} \mathrm{GAE} \mathrm{g}^{-1}$ ) and lemon balm (7.6\%, from $66.2 \pm 0.6 \mathrm{mg} \mathrm{GAE} \mathrm{g}^{-1}$ to $\left.71.2 \pm 0.6 \mathrm{mg} \mathrm{GAE} \mathrm{g}^{-1}\right)$. The storage time did not affect the total phenolic content significantly $(p \leq 0.05)$ for oregano (from 93.4 $\pm 2.2 \mathrm{mg} \mathrm{GAE} \mathrm{g}^{-1}$ to $91.2 \pm 1.6 \mathrm{mg} \mathrm{GAE} \mathrm{g}^{-1}$ ) and thyme (from $49.2 \pm 1.1 \mathrm{mg} \mathrm{GAE} \mathrm{g}^{-1}$ to $50.0 \pm 1.2 \mathrm{mg} \mathrm{GAE}$ $\mathrm{g}^{-1}$ ), the retentions were $97.6 \%$ and $101.6 \%$, respectively.

The total antioxidant capacities of tinctures and standard drugs (rosmarinic acid, caffeic acid, and L-ascorbic acid) were evaluated using DPPH assay. The scavenging effects of tinctures and standards on the DPPH radical were expressed as $\mathrm{IC}_{50}$, where lower values indicate higher antioxidant activity (Table 4). The six tinctures showed significant activity $\left(\mathrm{IC}_{50} \geq 19.2 \mu \mathrm{g} \mathrm{mL}^{-1}\right.$ ) when compared with the values obtained for L-ascorbic acid $\left(\mathrm{IC}_{50}=3.97 \mu \mathrm{g} \mathrm{mL}^{-1}\right.$ ), rosmarinic acid $\left(\mathrm{IC}_{50}=4.02 \mu \mathrm{g} \mathrm{mL}^{-1}\right)$, and caffeic acid $\left(\mathrm{IC}_{50}=4.24 \mu \mathrm{g} \mathrm{mL}^{-1}\right)$ standards. Among tinctures, oregano exhibited the strongest activity with an $\mathrm{IC}_{50}$ value of $19.2 \mu \mathrm{g} \mathrm{mL}^{-1}$ followed by lemon balm and peppermint at
Table 4 Total phenolic content and antioxidant activity of analyzed standards and tinctures

\begin{tabular}{|c|c|c|c|c|c|c|c|}
\hline \multirow[t]{3}{*}{ Tinctures/Standards } & \multicolumn{2}{|c|}{$\begin{array}{l}\text { Total phenolic (mg } \\
\text { GAE }^{\mathrm{a}} \mathrm{g}^{-1} \text { ) }\end{array}$} & \multicolumn{5}{|c|}{ Antioxidant activity } \\
\hline & \multirow[t]{2}{*}{ Initial day } & \multirow[t]{2}{*}{ Final day } & \multicolumn{2}{|c|}{ Inhibition (\%) } & \multirow{2}{*}{$\begin{array}{l}\mathrm{IC}_{50}^{\mathrm{b}} \\
(\mu \mathrm{g} \\
\left.\mathrm{mL}^{-1}\right)\end{array}$} & \multirow[t]{2}{*}{$1 / \mathrm{IC}_{50}$} & \multirow[t]{2}{*}{$\mathrm{mg} \mathrm{AAE}^{\mathrm{c}} \mathrm{g}^{-1}$} \\
\hline & & & Initial day & Final day & & & \\
\hline Lemon balm & $66.2 \pm 1.7^{\mathrm{a}}$ & $71.2 \pm 0.6^{\mathrm{f}}$ & $33.0 \pm 3.8^{\mathrm{a}^{*}}$ & $31.1 \pm 3.1^{\mathrm{a}^{*}}$ & 30.2 & 0.033 & 131.5 \\
\hline Oregano & $93.4 \pm 2.2^{\mathrm{b}}$ & $91.2 \pm 2.2^{\mathrm{b}}$ & $39.0 \pm 2.4^{\mathrm{b}^{*}}$ & $38.3 \pm 2.1^{\mathrm{b}^{*}}$ & 19.2 & 0.052 & 206.8 \\
\hline Peppermint & $65.8 \pm 1.2^{\mathrm{a}}$ & $70.9 \pm 0.5^{f}$ & $32.7 \pm 2.4^{\mathrm{a}^{*}}$ & $31.5 \pm 3.7^{\mathrm{a}^{*}}$ & 31.0 & 0.032 & 128.1 \\
\hline Rosemary & $38.8 \pm 0.4^{\mathrm{c}}$ & $43.3 \pm 1.3^{\mathrm{g}}$ & $56.1 \pm 2.8^{c}$ & $65.1 \pm 2.6^{\mathrm{e}}$ & 96.2 & 0.010 & 41.27 \\
\hline Sage & $34.1 \pm 1.1^{\mathrm{d}}$ & $31.4 \pm 0.9^{h}$ & $48.8 \pm 1.4^{\mathrm{d}}$ & $49.2 \pm 2.1^{\mathrm{d}}$ & 77.2 & 0.013 & 51.42 \\
\hline Thyme & $49.2 \pm 1.1^{\mathrm{e}}$ & $50.0 \pm 1.2^{\mathrm{e}}$ & $58.4 \pm 1.7^{\mathrm{c}}$ & $58.9 \pm 2.3^{\mathrm{c}}$ & 96.0 & 0.010 & 41.35 \\
\hline Ascorbic acid & - & - & - & - & 3.97 & 0.250 & 1000 \\
\hline Rosmarinic acid & - & - & - & - & 4.02 & 0.250 & 987.6 \\
\hline Caffeic acid & - & - & - & - & 4.24 & 0.238 & 936.3 \\
\hline
\end{tabular}

Different letters (a, b, c, d, e, f, and g) denote significant differences $(p \leq 0.05)$

*20-fold diluted samples

${ }^{\mathrm{a}} \mathrm{GAE}$ : gallic acid equivalent

${ }^{\mathrm{b}} \mathrm{IC}_{50}$ : half-inhibitory concentration

${ }^{\mathrm{c}} \mathrm{AAE}$ : ascorbic acid equivalent 


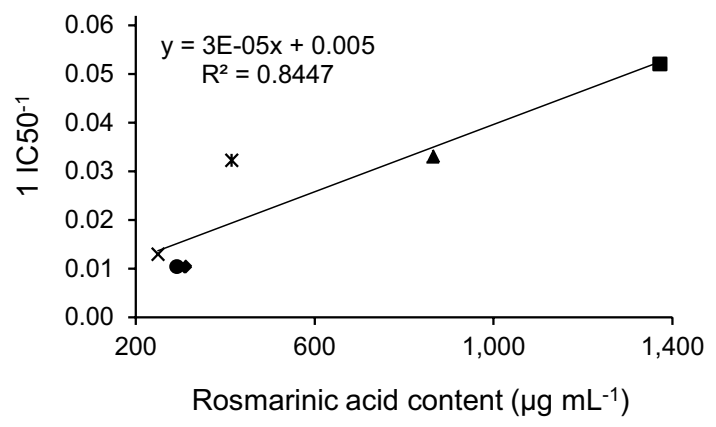

Fig. 2 Linear correlation between $1 \mathrm{IC}^{-1}$ values and rosmarinic acid in various tinctures from Lamiaceae species. Different signs denote oregano $(\mathbf{\square})$, lemon balm $(\boldsymbol{\Delta})$, peppermint $(*)$, sage $(\mathrm{x})$, rosemary $(\bullet)$, and thyme $(\diamond)$

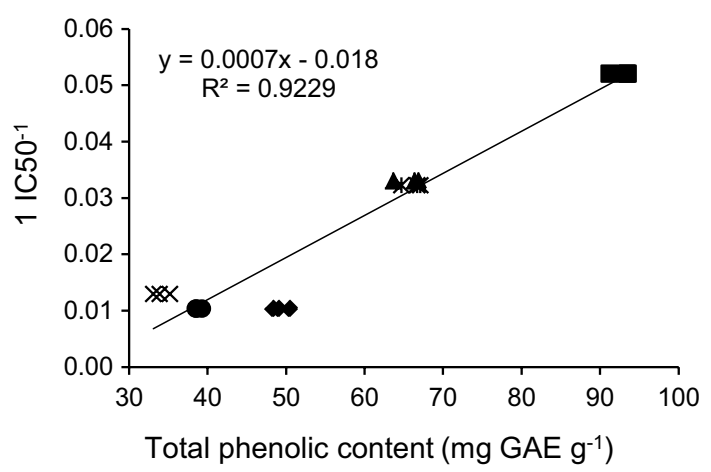

Fig. 3 Linear correlation between $1 \mathrm{IC}^{-1} 0^{-1}$ values and total phenolic content in various tinctures from Lamiaceae species. Different signs denote oregano $(\boldsymbol{\square})$, lemon balm $(\boldsymbol{\Delta})$, peppermint $(*)$, sage $(\mathrm{x})$, rosemary $(\mathbf{O})$, and thyme $(\bullet)$

$\mathrm{IC}_{50}$ values of $30.2 \mu \mathrm{g} \mathrm{mL}^{-1}$ and $31.0 \mu \mathrm{g} \mathrm{mL}^{-1}$, respectively. A weak activity was observed with the thyme $\left(\mathrm{IC}_{50}=96.0 \mu \mathrm{g} \mathrm{mL}^{-1}\right)$ and rosemary $\left(\mathrm{IC}_{50}=96.2 \mu \mathrm{g} \mathrm{mL}^{-1}\right)$. Similarly, a reduced antioxidant effect was noticed in sage $\left(\mathrm{IC}_{50}=77.2 \mu \mathrm{g} \mathrm{mL}^{-1}\right)$.

The $1 / \mathrm{IC}_{50}$ coefficients were also calculated to determine the correlation between antioxidant activity and the rosmarinic acid and total phenolic content in various tinctures of Lamiaceae species. The results of Fig. 2 suggest that $84.5 \%$ of the antioxidant activity in tinctures is due to the contribution of rosmarinic acid. Part of the remaining $15.5 \%$ is probably due to the other phenolic constituents, as evidenced by Fig. 3. This figure displays a high correlation $(92.3 \%)$ between antioxidant activity and total phenolic content in various tinctures, furthermore illustrates that the antioxidant properties of oregano, lemon balm, peppermint, and rosemary are due to the concentration of phenolic compounds and that the antioxidant activity of sage and thyme may also be related to other antioxidant secondary metabolites. The antioxidant capacity of plant extracts and standards was also expressed in terms of L-ascorbic acid equivalents (AAE), as shown in Table 4.

In this study, the antioxidant activity of tinctures was also monitored during storage, similar to the total phenolic content. For this, we observed the percentage inhibitory effect of 20-fold diluted oregano, lemon balm, and peppermint tinctures and fivefold diluted rosemary, sage, and thyme tinctures during the storage. The results obtained from the percentage DPPH assay showed that antioxidant properties of oregano $(39.0 \pm 2.4-38.3 \pm 2.1 \%)$, lemon balm $(33.0 \pm 3.8-31.1 \pm 3.1 \%)$, peppermint $(32.7 \pm 2.4$ $-31.5 \pm 3.7 \%)$, sage $(48.8 \pm 1.4-49.2 \pm 2.1 \%)$, and thyme $(58.4 \pm 1.7-58.9 \pm 2.3 \%)$ tinctures had no significant change $(p \leq 0.05)$, while the antioxidant effect of rosemary possessed increasing $(16 \%$, from $56.1 \pm 2.8 \%$ to $65.1 \pm 2.6 \%)$ over the storage period.

\section{Discussion}

A large number of herbal preparations are available in the market that have a variety of therapeutic effects on the human body and health. Even though there is wide acceptability and availability of herbal products in the form of dietary supplements, the attention toward their quality control is not at par with modern medicines (Kaur et al. 2016). Shelf life gives the point at which a product is unable to meet the requirements that it is supposed to, and may even be considered dangerous for consumers (Laher et al. 2013). The present study examined the stability characteristics of six tinctures, aiming to obtain more information for the longterm storage possibilities of rosmarinic acid, which has a therapeutic effect.

By validated the HPLC-DAD method, we demonstrated significant differences $(p \leq 0.05)$ in rosmarinic acid change during the 168-day storage. Several authors demonstrated that higher temperatures hydrolyze rosmarinic acid to caffeic acid, thereby causing significant loss. However, our research has shown that this phenomenon also exists at ambient temperature, especially during a long storage period. Relevant comparison of the data from our HPLC analysis is quite elaborate, as we did not find any literature that would trace rosmarinic acid in a similar matrix in the long term. Zhang et al. (2012) in their study, the degradation of individual samples of rosmarinic acid, carnosol, and carnosic acid standards, as well as a mixture of the mixture of these three antioxidants in pure ethanolic solution, monitored for 13 days. They found that rosmarinic acid, either by itself in the ethanolic solution or present in the mixture solution, did not degrade appreciably under the 13-day study. These results are in agreement with our results in that rosmarinic acid as a standard has also had excellent long-term stability. Despite this, in "real" plant extract samples, we found 
that the rosmarinic acid is quite unstable. Table 3 shows that after a rapid decrease in rosmarinic acid, degradation stagnated, which was eventually followed by a slight decomposition. This stagnation was observed for oregano, lemon balm, and thyme after 55 days, while for rosemary and sage after 86 days. In the case of peppermint, this occurred after a longer storage period, viz. after 113 days. The decrease in the rosmarinic acid after these periods did not exceed $10 \%$ in either case.

In general, the phenolic acids are present as trans-isomers, and after exposure to various extreme conditions (more protic solvent, higher temperatures, longer storage times, etc.), degrade (isomerized) rapidly (Razboršek et al. 2021). The rapid decomposition of trans-rosmarinic acid to its cis-isomer in a protic organic solvent was observed by Razboršek (2011). The author found that after being stored for one day in daylight at ambient temperature, the content of trans-rosmarinic acid dissolved in ethanol decreased by approximately $25 \%$. In this study, we made a similar observation. It can be assumed that the unidentified peak labeled 2 is the cis-isomer of trans-rosmarinic acid (Fig. 1). It is difficult to compare our results with the study of Zorić et al. (2016) because they tested the stability of rosmarinic acid in aqueous extracts after in vitro digestion with human gastrointestinal enzymes. In spite of this, they found that the stability of pure rosmarinic acid was higher than that of rosmarinic acid from plant extracts, which was consistent with our study. We also found constant values in the increase in caffeic acid content, similar to the rosmarinic acid decomposition. However, the increase is not entirely consistent with the decrease observed for rosmarinic acid, so other mechanisms must play a role because the formation of caffeic acid was significantly lower than the rosmarinic acid degradation. One explanation for this, that rosmarinic acid is not completely converted to caffeic acid. This phenomenon is also confirmed by the tendency of the standard solution to decompose (Fig. 1). Another explanation may be that the resulting caffeic acid is quite unstable and decomposes further into other compounds. These results also show that in tinctures the rate of rosmarinic acid degradation did not fit the first-order kinetic that lead to the impossibility of predicting shelf life at $25^{\circ} \mathrm{C}$ by the Arrhenius law.

During storage, the total phenolic content in rosemary, peppermint, and lemon balm showed a tendency to increase. Other authors have previously described this phenomenon and reported a possible increment in polyphenolic compounds due to the reactions of antioxidant character or formation of new compounds of antioxidant character. In addition, must be considered the possibility that these new compounds could react with the Folin-Ciocalteu's reagent, which could be significantly increase the total phenolic content (Castro-López et al. 2016). Based on the chromatographic profile and HPLC analysis of lemon balm, this phenomenon may be due to the increase in caffeic acid, which was quite high $(-54.9 \%)$. As shown in Fig. 1, in the case of peppermint and rosemary, the increase in total phenolic content cannot be highly related to caffeic acid, as increases, in other minor compounds can also be observed in the chromatogram, especially for rosemary.

From our data, oregano stands out with an efficient antioxidant ability, which is correlated to the high total phenolic content, followed by lemon balm and peppermint, as compared to rosemary, sage, and thyme with the lowest values. The high correlation between the values of total phenolic concentration in plant extracts and DPPH radical scavenging activity is well documented. In this regard, Chrpová et al. (2010) showed a linear correlation $\left(R^{2}=0.96\right)$ between antioxidant activity and phenolic contents of lemon balm, peppermint, oregano, Greek oregano, sage, and winter savory plant extracts. In this study, a direct correlation was found between rosmarinic acid content and the antioxidant capacity $\left(R^{2}=0.85\right)$ in various Lamiaceae species in the DPPH model. The excellent correlation between rosmarinic acid and antioxidant activity is due to the structure of its molecule, namely the presence of four hydrogens and two electroactive catecholic groups, which can neutralize free radicals by an electron/proton donor mechanism (Vatankhah 2018). A similar trend in the correlation between $\left(R^{2}=0.64\right)$ rosmarinic acid content and antioxidant activity of different Mentha spicata clones were also presented by Fletcher et al. (2005). Contrary to us, Lamien-Meda et al. (2010) found a slightly worse correlation $\left(R^{2}=0.34\right)$ for sage, although their analyzed sage samples had higher rosmarinic acid content. In the case of oregano, thyme, and basil species Lagouri and Nisteropoulou (2009) observed high positive correlations between total phenolic $\left(R^{2}=0.72\right)$, rosmarinic acid $\left(R^{2}=0.85\right)$ and DPPH activity. Yan et al. (2016) analyzed the 42 accessions of oregano, but no correlation was found between the rosmarinic acid content and the antioxidant capacity measured by oxygen radical absorbance capacity (ORAC).

\section{Conclusion}

The present study demonstrates the importance of storage conditions for the stability of rosmarinic acid as a marker compound and the consideration of this biologically active compound as the main quality factor in Lamiaceae tinctures. Although considerable differences were found between the rosmarinic acid content of the tinctures tested, the behavior of the compound was similar in terms of the decomposition tendency. Overall, in our study, following the EMA-HMPC guidelines, we accepted a maximum of $10 \%$ marker compound degradation for adequate efficacy. According to these guidelines, the shelf life of thyme tincture was estimated less 
than 27 days. However, in the case of lemon balm, oregano, and sage tincture, the shelf life was slightly better, viz. less than 55 days. Peppermint and rosemary showed the best shelf life, which was $\leq 113$ days. In addition, our research has also shown that tinctures containing rosmarinic acid have good antioxidant properties. It is important to note also that our research highlighted the need for further investigation in this area. First, it is important to conduct several studies under different storage conditions. Furthermore, monitoring of other relevant active substances could be useful to draw a more comprehensive conclusion.

Acknowledgements The publication is supported by the EFOP-3.6.3VEKOP-16-2017-00008 project. The project is co-financed by the European Union and the European Social Fund.

Funding Open access funding provided by Széchenyi István University (SZE).

\section{Declarations}

Conflict of interest The authors declare that they have no conflicts of interest.

Open Access This article is licensed under a Creative Commons Attribution 4.0 International License, which permits use, sharing, adaptation, distribution and reproduction in any medium or format, as long as you give appropriate credit to the original author(s) and the source, provide a link to the Creative Commons licence, and indicate if changes were made. The images or other third party material in this article are included in the article's Creative Commons licence, unless indicated otherwise in a credit line to the material. If material is not included in the article's Creative Commons licence and your intended use is not permitted by statutory regulation or exceeds the permitted use, you will need to obtain permission directly from the copyright holder. To view a copy of this licence, visit http://creativecommons.org/licenses/by/4.0/.

\section{References}

Anonymous (2018) EMA/HMPC/162241/2005 Rev.3. European Medicine Agency. Committee on Herbal Medicinal products. Guideline on specifications: test procedures, herbal preparations and herbal medicinal products/traditional herbal medicinal products. Accessed 21 November 2020

Bernatoniene J, Cizauskaite U, Ivanauskas L, Jakstas V, Kalveniene Z, Kopustinskiene DM (2016) Novel approaches to optimize extraction processes of ursolic, oleanolic and rosmarinic acids from Rosmarinus officinalis leaves. Ind Crops Prod 84:72-79. https://doi. org/10.1016/j.indcrop.2016.01.031

Bilia AR, Bergonzi MC, Gallori S, Mazzi G, Vincieri FF (2002) Stability of constituents of Calendula, Milk-thistle and Passionflower tinctures by LC-DAD and LC-MS. J Pharm Biomed Anal 30:613624. https://doi.org/10.1016/S0731-7085(02)00352-7

Castro-López C, Sánchez-Alejo EJ, Saucedo-Pompa S, Rojas R, Aranda-Ruiz J, Martínez-Avila GCG (2016) Fluctuations in phenolic content, ascorbic acid and total carotenoids and antioxidant activity of fruit beverages during storage. Heliyon 2:e0152. https://doi.org/10.1016/j.heliyon.2016.e00152
Chrpová D, Kouřimská L, Gordon MH, Heřmanová V, Roubíčková I, Pánek J (2010) Antioxidant activity of selected phenols and herbs used in diets for medical conditions. Czech J Food Sci 28:317-325

Fachel FNS, Schuh RS, Veras KS, Bassani VL, Koester LS, Henriques AT, Braganhol E, Teixeira HF (2019) An overview of the neuroprotective potential of rosmarinic acid and its association with nanotechnology-based delivery systems: a novel approach to treating neurodegenerative disorders. Neurochem Int 122:47-58. https://doi.org/10.1016/j.neuint.2018.11.003

Fletcher RS, McAuley C, Kott LS (2005) Novel Mentha spicata clones with enhanced rosmarinic acid and antioxidant activity. Acta Hortic 680:31-36

Gafner S, Bergeron C (2005) The challenges of chemical stability testing of herbal extracts in finished products using state-of-the-art analytical methodologies. Curr Pharm Anal 1:203-215. https:// doi.org/10.2174/1573412054022734

Kaur I, Suthar N, Kaur J, Bansal Y, Bansal G (2016) Accelerated stability studies on dried extracts of Centella asiatica through chemical, HPLC, HPTLC, and biological activity analyses. J Evid Based Complementary Altern Med 21:127-137. https:// doi.org/10.1177/2156587216661468

Kumadoh D, Ofori-Kwakye K (2017) Dosage forms of herbal medicinal products and their stability considerations - an overview. J Crit Rev 4:1-8

Kumadoh D, Adotey J, Ofori-Kwakye K, Kipo SL, Prah T, Patterson S (2015) Development of oral capsules from Enterica herbal decoction-a traditional remedy for typhoid fever in Ghana. J Appl Pharm Sci 5:83-88. https://doi.org/10.7324/JAPS.2015. 50414

Lagouri V, Nisteropoulou E (2009) Antioxidant properties of $O$. Onites, T. vulgaris and $O$. basilicum species grown in Greece and their total phenol and rosmarinic acid content. J Food Lipids 16:484498. https://doi.org/10.1111/j.1745-4522.2009.01161.x

Laher F, Aremu AO, Van Staden J, Finnie JF (2013) Evaluating the effect of storage on the biological activity and chemical composition of three South African medicinal plants. S Afr J Bot 88:414-418. https://doi.org/10.1016/j.sajb.2013.09.003

Lamien-Meda A, Nell M, Lohwasser U, Börner A, Franz C, Novak J (2010) Investigation of antioxidant and rosmarinic acid variation in the sage collection of the genebank in Gatersleben. J Agric Food Chem 58:3813-3819. https://doi.org/10.1021/jf903993f

Lo YT, Shaw PC (2019) Application of next-generation sequencing for the identification of herbal products. Biotechnol Adv. https://doi. org/10.1016/j.biotechadv.2019.107450

Mishra LK, Sarkar D, Shetty K (2020) Human health-relevant bioactives and associated functionalities of herbs in the Lamiaceae family. In: Shetty K, Sarkar D (Eds.), CRC Press, Boca Raton, FL, USA, pp. 115-132.

Prosen H, Pendry B (2016) Determination of shelf life of Chelidonium majus, Sambucus nigra, Thymus vulgaris and Thymus serpyllum herbal tinctures by various stability-indicating tests. Phytochem Lett 16:311-323. https://doi.org/10.1016/j.phytol.2016.05.012

Razboršek MI (2011) Stability studies on trans-rosmarinic acid and GC-MS analysis of its degradation product. J Pharm Biomed Anal 55:1010-1016. https://doi.org/10.1016/j.jpba.2011.04.003

Razboršek MI, Ivanović M, Kolar M (2021) Validated stability-indicating GC-MS method for characterization of forced degradation products of trans-caffeic acid and trans-ferulic acid. Molecules 26:2475. https://doi.org/10.3390/molecules26092475

Romm A, Ganora L, Hoffmann D, Yarnell E, Abascal K, Coven M (2010) Fundamental principles of herbal medicine. In: Romm A (Ed.), Churchill Livingstone, London, UK, pp. 27-74.

Runtuwene J, Cheng KC, Asakawa A, Amitani H, Amitani M, Morinaga A, Takimoto Y, Kairupan BHR, Inui A (2016) Rosmarinic acid ameliorates hyperglycemia and insulin sensitivity in diabetic rats, potentially by modulating the expression of PEPCK 
and GLUT4. Drug Des Devel Ther 10:2193-2202. https://doi.org/ 10.2147/DDDT.S108539

Shetty K (2008) Biosynthesis and medical applications of rosmarinic acid. J Herbs Spices Med Plants 8:161-181. https://doi.org/10. 1300/J044v08n02_05

Sik B, Hanczné EL, Kapcsándi V, Zs A (2020) Conventional and nonconventional extraction techniques for optimal extraction processes of rosmarinic acid from six Lamiaceae plants as determined by HPLC-DAD measurement. J Pharm Biomed Anal. https://doi. org/10.1016/j.jpba.2020.113173

Singleton VL, Rossi JA (1965) Colorimetry of total phenolics with phosphomolybdic-phosphotungstic acid reagents. Am J Enol Vitic $16: 144-158$

Swamy MK, Sinniah UR, Ghasemzadeh A (2018) Anticancer potential of rosmarinic acid and its improved production through biotechnological interventions and functional genomics. Appl Microbiol Biotechnol 102:7775-7793. https://doi.org/10.1007/ s00253-018-9223-y

Testoni LD, de Souza AB, de Krueger C, Quintão NLM, Couto AG, Bresolin TMB (2019) Quantification of Sambucus nigra (Adoxaceae) markers related to tincture stability. Nat Prod Commun 14:59-62. https://doi.org/10.1177/1934578X1901400116

Thakur L, Ghodasra U, Patel N (2011) Dabhi M (2011) Novel approaches for stability improvement in natural medicines. Pharmacogn Rev 5:48-54. https://doi.org/10.4103/0973-7847.79099
Vatankhah E (2018) Rosmarinic acid-loaded electrospun nanofibers: In vitro release kinetic study and bioactivity assessment. Eng Life Sci 18:732-742. https://doi.org/10.1002/elsc.201800046

WHO (2019) World Health Organization. WHO global report on traditional and complementary medicine, Geneva

Yan F, Azizi A, Janke S, Schwarz M, Zeller S, Honermeier B (2016) Antioxidant capacity variation in the oregano (Origanum vulgare L.) collection of the German National Genebank. Ind Crops Prod 92:19-25. https://doi.org/10.1016/j.indcrop.2016.07.038

Zhang Y, Smuts JP, Dodbiba E, Rangarajan R, Lang JC (2012) Degradation study of carnosic acid, carnosol, rosmarinic acid, and rosemary extract (Rosmarinus officinalis L.) assessed using HPLC. J Agric Food Chem 60:9305-9314

Zorić Z, Markić J, Pedisić S, Bučević-Popović V, Generalić-Mekinić I, Grebenar K, Kulišić-Bilušić T (2016) Stability of rosmarinic acid in aqueous extracts from different Lamiaceae species after in vitro digestion with human gastrointestinal enzymes. Food Technol Biotechnol 54:97-102

Publisher's Note Springer Nature remains neutral with regard to jurisdictional claims in published maps and institutional affiliations. 